ICACCG2020 30-31 July, 2020, Ansal University, Gurgaon, India

International Journal of Technical Research \& Science (Special Issue)

\title{
PHYSIOCHEMICAL ANALYSIS OF GOMTI RIVER IN LUCKNOW CITY, UTTAR PRADESH
}

\author{
MaazShamsi $^{1}$, Sangeeta Bajpai ${ }^{1}$, Monika Kamboj ${ }^{1}$, Paritosh Srivastava ${ }^{2}$, Anamika Paul ${ }^{3}$ \\ Aarti Vaish $^{3}$ \\ E-Mail Id: ${ }^{1}$ s_pbajpai @yahoo.com, ${ }^{2}$ paritosh.srivastava@ niu.edu.in \\ ${ }^{1}$ Amity School of Applied Sciences, Amity University, Lucknow, Uttar Pradesh, India \\ ${ }^{2}$ Noida International University, Greater Noida, Uttar Pradesh India \\ ${ }^{3}$ School of Engineering \& Technology, Ansal University, Gurgaon, Haryana, India
}

\begin{abstract}
River water is significant for every living organism. In Indian mythology rivers are given the status of Goddess and were worship. Modernization and urbanization has polluted the river water and degraded their status. Assessment of water quality and determination of pollution level has become a big necessity today. In view if above, the present work envisages findings of various physicochemical characteristics ( $\mathrm{pH}$, hardness, chloride, alkalinity, etc.) examined for Gomti river water samples collected from three different locations of Lucknow. This study was meant to determine the recent status of River Gomti along the Lucknow stretch. Results of the study indicated that river water is highly contaminated and not suitable for recreational activities.
\end{abstract}

Keywords: Gomti River, Physiochemical studies.

\section{INTRODUCTION}

River Gomti, one of the major affluent of river Ganga triggers from a reservoir located near Madhotanda (Miankot) with an altitude of $200 \mathrm{~m}$. Its origin starts about $50 \mathrm{~km}$ south of the Himalaya foot-hills and about $3 \mathrm{~km}$ east of Pilibhit in Uttar Pradesh. From public health point of view,increase in water pollution level due to dumping of unwanted substance into water bodies has created a big necessity for assessment of river water quality used for drinking and domestic purposes. Water quality is one of the keyconcerns for human beings, due to its direct link with all living things.Besides, urbanization, dumping of religious materials viz. flowers, food, sweets, clothes etc. in the river has increased the pollution level and deterioration of river water quality of the river Gomti which is also a major source for drinking/ portable water supply for urban population. Unprocessed industrial and household waste along with sewage are disposed directly into it through gutters has increased the water contamination to a great extent. . Festivals are an integral part of ritual and diverse cultural heritage of India.

Months from September to November are full of Hindu festivals. Navaratri, Dussehra, Ganpati utsav, Deepawali are some of the famousHindu festivals celebrated during this tenure. On these occasions, every year, thousands of small to large idols of Lord Ganesh,Goddess Durga and many more are engrossed in the river water. Innumerable biodegradable and non-biodegradable materials viz.plaster of paris, papers, clay, colors, jutes, clothes, wooden frame, thermocol etc. are present in them].Reports on presence of heavy metals like lead, chromium, nickel, cadmium and zinc to a significant extent are also available .A number of persistent colors and toxic chemicals leach from these idols and strewin the river water. These toxic non-biodegradable chemicals enter into human bodies through food chain. In the present work, various physiochemical studies have been made in order to find out some possible methods for water quality improvement and its protection.

\section{SAMPLING SITES}

Three sampling sites were selected namely Red pakka pul(I), Hanuman Setu (II) and Indira Dam(III). Samples were collected and analyzed.

\section{MATERIAL AND METHODS}

Three sampling sites were selected which cover the residential Lucknow region namely Red pakka pul(I), Hanuman Setu (II) and Indira Dam(III). The samples of water were collected from both the banks and middle stream of the river on each site. For collection of water sample, sampling bottles were soaked overnight in $10 \%$ HNO3 solution, which were then washed twice with double distilled water and rinsed three times with stream water, leaving the last rinse for five minute to equilibrate. Water samples were collected in acidified PVC bottles. Preservation and transportation of the samples to the laboratory were done following standard methods. (APHA1998). The ice boxes were used during transportation to avoid unpredictable changes in physiochemical characteristics. The containers were carefully filled just to overflowing, without passing air bubbles through sample or trapping air bubbles in sealed containers. Preparation of the containers included washing with detergent, rinsing with tap water, ultrapure water (Millipore) and air dried. Each sample was identified clearly and indelibly by allocating a unique identification number. Color, odor and taste in water are 
ICACCG2020 30-31 July, 2020, Ansal University, Gurgaon, India

International Journal of Technical Research \& Science (Special Issue)

ISSN No.:2454-2024 (online) determined physically. $\mathrm{PH}$ value in water is determined by using $\mathrm{pH}$ meter (Labtronics LT-49). Total dissolved solids in water were determined by TDS measurement apparatus. Total Hardness in water was determined by EDTA complexometric titration using EDTA as Titrant and EBT indicator. The alkalinity was examined by acid base titration using indicators. Dissolved oxygen and Chloride were estimated by iodometric titration and argenometric titration respectively. Determination of sulphatein water was done byNephelometry method using Nephelometric turbidity meter. Flame photometer was used for the determination of sodium and potassium.

\section{RESULTS AND DISCUSSION}

Various parameters observed during water analysis of Gomti River at Lucknow are listed in The data collected by sampling at various locations are analyzed and the results are discussed.

Table-4.1 The Data Collected by Sampling at Various Locations

\begin{tabular}{|c|c|c|c|c|c|c|}
\hline Parameters & Units & $\begin{array}{l}\text { Requirement } \\
\text { (Acceptable } \\
\text { limit) [5] }\end{array}$ & $\begin{array}{l}\text { Permissible } \\
\text { limit in the } \\
\text { absence of } \\
\text { Alternate } \\
\text { Source }\end{array}$ & $\begin{array}{l}\text { Sampling } \\
\text { location } 1 \\
\text { Pakka Pul }\end{array}$ & $\begin{array}{l}\text { Sampling } \\
\text { location II } \\
\text { Hanuman } \\
\text { Setu }\end{array}$ & $\begin{array}{l}\text { Sampling location } \\
\text { III } \\
\text { Indira Dam }\end{array}$ \\
\hline $\mathrm{pH}$ value & & $6.5-8.5$ & No relaxation & 6.6 & 6.72 & 6.84 \\
\hline TDS & $\mathrm{mg} / \mathrm{L}$ & 500 & 2000 & 1385 & 1310 & 1415 \\
\hline \begin{tabular}{|l} 
Total \\
Hardness(as \\
CaCO3)
\end{tabular} & $\mathrm{mg} / \mathrm{L}$ & 200 & 600 & 545 & 570 & 535 \\
\hline $\begin{array}{l}\text { Total } \\
\text { Alkalinity }\end{array}$ & $\mathrm{mg} / \mathrm{L}$ & 200 & 600 & 520 & 545 & 515 \\
\hline $\begin{array}{l}\text { Chloride } \\
\text { Content }\end{array}$ & $\mathrm{mg} / \mathrm{L}$ & 250 & 1000 & 390 & 376 & 315 \\
\hline $\begin{array}{l}\text { Sulphate (as } \\
\text { SO4) }\end{array}$ & $\mathrm{mg} / \mathrm{L}$ & 200 & 400 & 167 & 215 & 189 \\
\hline $\begin{array}{l}\text { Phenolic } \\
\text { compounds }\end{array}$ & $\mathrm{mg} / \mathrm{L}$ & 0.0001 & 0.0002 & 0.00098 & 0.00010 & 0.00010 \\
\hline D.O. & $\mathrm{mg} / \mathrm{L}$ & 8 & 10 & 15 & 18 & 16.5 \\
\hline
\end{tabular}

\section{$4.1 \mathrm{pH}$}

The $\mathrm{pH}$ is a significant parameter for analyzing the quality of water and the extent of the pollution in the river water. A review of $\mathrm{pH}$ data with respected to primary water quality criteria prescribed by Environmental Protection Act. 1986 in terms of $\mathrm{pH}$ required in the range 6.5-8.5 for class 'A'water. $\mathrm{pH}$ is found to be within the range at the three sites, but is at lower site due to industrial and domestic discharge at this place which also affects the taste of water at the place. It has been observed that $\mathrm{pH}$ of water gets drastically changed with time due to temperature changes, exposure to air and biological activity.

\subsection{Total Dissolved Solids (TDS)}

Total dissolved solids in water are mostly salts of carbonates, bicarbonates, chlorides, phosphates and nitrates of calcium, magnesium, sodium, potassium and manganese, organic matter, salt and other particles. The maximum acceptable range of TDS in water is $500 \mathrm{mg} / \mathrm{L}$. The analysis of the three water samples showed the values nearer to the permissible limit.

\subsection{Total Hardness}

Sulphates, Chlorides, Carbonates and Bicarbonates of calcium and magnesium are responsible for the total hardness. As the presence of organic matter increases the level of dissolved oxygen decreases thereby increasing 
ICACCG2020 30-31 July, 2020, Ansal University, Gurgaon, India

International Journal of Technical Research \& Science (Special Issue)

ISSN No.:2454-2024 (online)

the concentration of carbon dioxide which gives more carbonate which hen combine with calcium and magnesium ion gives hardness to the water. The total hardness found in water samples were 545, 570 and 535 $\mathrm{mg} / \mathrm{l}$ respectively.

\subsection{Total Alkalinity}

Alkalinity of water is the capacity of the water to accept protons. It may be defined as the quantitative capacity of an aqueous medium to react with hydrogen ions to $\mathrm{pH} 8.3$ (phenolphthalein alkalinity) and then to $\mathrm{pH} 3.7$ (total alkalinity or methyl orange alkalinity). Thealkalinities found in all the three water samples were $520 \mathrm{mg} / \mathrm{L}, 545 \mathrm{mg} / \mathrm{L}$ and $515 \mathrm{mg} / \mathrm{L}$ respectively.

\subsection{Chloride Content}

Chloride in the form of chloride ion is one of the major inorganic anions in water and wastewater. The chloride concentration is higher in wastewater than in raw water because sodium chloride is a common article of diet and passes unchanged through the digestive system. Along the sea coast chloride may be present in high concentration because of leakage of salt water into the sewage system. It also may be increased by industrial process. In potable water, the salty taste produced by chloride concentration is variable and depends on the chemical composition of water. Some waters containing $250 \mathrm{mg} / \mathrm{L}$ may have a detectable salty taste if sodium cation is present. On the other hand, the typical salty taste may be absent in waters containing as much as $1000 \mathrm{mg} / \mathrm{L}$ when the predominant cations are calcium and magnesium. In addition, a high chloride contents may harm metallic pipes and structures as well as growing plants. The chloride content found in all three water samples were found to be $390 \mathrm{mg} / \mathrm{L}, 376 \mathrm{mg} / \mathrm{L}$ and $315 \mathrm{mg} / \mathrm{L}$ respectively.

\subsection{Sulphates (as SO4)}

Sulphates are widely distributed in nature and may be present in natural water in concentration ranging from few hundred to several thousand $\mathrm{mg} / \mathrm{L}$. Sulphates occur naturally in numerous minerals including barite, epsomite and gypsum. These dissolved minerals contribute to the mineral content of drinking water. Sulphate is a second most abundant ion in sea water. Thesulphate content in all the three samples were $167 \mathrm{mg} / \mathrm{L}, 215 \mathrm{mg} / \mathrm{L}$ and $189 \mathrm{mg} / \mathrm{L}$.

\subsection{Phenolic Compounds}

Most phenols react with 4-amino antipyrine at $\mathrm{pH} 7.9+0.1$ in the presence of potassium ferricyanide to form a colored antipyrine dye. This dye is extracted from water with Chloroform and the absorbance is measured at $460 \mathrm{~nm}$. The minimum detectable quantity is $1 \mu \mathrm{g}$ of phenol/liter in 460 distillate. This method is more sensitive and is adoptive for use in water sample containing less than $1 \mathrm{mg}$ of phenol/liter. The Phenolic content were found as $0.00098 \mathrm{mg} / \mathrm{L}, 0.00010 \mathrm{mg} / \mathrm{L}$ and $0.00010 \mathrm{mg} / \mathrm{L}$ respectively in all the three water samples taken.

\subsection{Dissolved Oxygen (DO)}

DO not less than 3-5 mg/l is essential for the survival of aquatic life D.O. at every location is above the permissible value. So these sites are least polluted from industrial, sewage and domestic waste. The dissolved level declines during rainy season as compared to summer and winter as in rainy season runoffs from the content of dissolved oxygen is sufficient enough so that the aquatic animals can survive here.

\section{CONCLUSION}

The water pollution level of Gomti riverwas found to be very high thereby indicating the poor quality of water which is unsafe and non - acceptable for any purpose. The level of all the indicators is above the standards, which are the serious concern for the ecology of the river. The deterioration of water was due to 26 drains along its stretch. Various industrial waste, agricultural waste and domestic wastes are the main cause of increasing urbanization and population resulted in the increase in the content of heavy metals that result in pollution of river water. Due to huge amount of organic and inorganic matter, river lost its self-purification nature resulting higher bacterial growth. That is why it is very necessary to treat the waste coming from industries and other sources before merging into the river so that aquatic species as well as human life may not get affected.

\section{REFERENCES}

[1] Vyas A, Bajpai A, Verma N (2008), Water quality improvement after shifting of idol immersion site: A case study of upper Lake, Bhopal, India. Environ Monit Assess 145: 437-443.

[2] Singh K P, Mohan Di, Singh V K, Malik A (2005), Studies on distribution and fractionation of heavy metals in Gomti River sediments -a tributary of a Ganges, India.J.Hydro 312:14-27.

[3] SmithaAD,Shivshanker AP, (2013) Physicochemical analysis of the freshwater at river Kapila, Nanjangudu Industrial area, Mysore, India, J.Chem. Biol. Phys. Sci25: 9-62.

[4] Sheetal P, Mussadiq M, Budhlani G N, (2014), Ganesh idol immersion and its impact on water quality of Tapti River, Burhanpur, MP, India, 34-40. 
[5] Indian Drinking water standards, Central Ground water Board, IS 10500(2012).

[6] V Dutta, U Sharma, K Iqbal, R Kumar, AK Pathak (2018) Impact of river channelization and riverfront development on fluvial habitat: evidence from Gomti River, a tributary of Ganges, India - Environmental Sustainability, 2018 Volume 2 Issue 1

[7] Julieta Peluso, Carolina M.Aronzon; María del CarmenRíos de Molina,Dante E.Rojas DiegoCristos Cristina, S.Pérez Coll (2020). Integrated analysis of the quality of water bodies from the lower Paraná River basin with different productive uses by physicochemical and biological Indicators, Environmental Pollution Volume 263.

[8] WHO: World Health Organization. (2011) Guidelines for drinking-water quality. World Health Organization Press. Geneva, Switzerland; 2011.

[9] V. P. Danilov, E. A. Frolova, D. F. Kondakov,L. B. Sveshnikova (2019) Application of Physicochemical Analysis to Developing and Studying Deicing Agents Russian Journal of Inorganic Chemistry volume 64.

[10] Nimisha Srivastava and R.C. Arya (2020) Seasonal changes in water quality index at different sites of Gomti river, Lucknow South Asian J. Food Technol. Environ., 6(1): 913-916 (2020) ISSN 2394-5168 (Print), 24546445(online).

[11] SS Mali, DK Singh, A Sarangi (2018).Assessing water footprints and virtual water flows in Gomti river basin of India. Current Science.

[12] Godfrey Bwire, David A. Sack, Atek Kagirita, Tonny Obala, Amanda K. Debes, Malathi Ram, Henry Komakech, Christine Marie Georgeand Christopher Garimoi Orach (2020)The quality of drinking and domestic water from the surface water sources (lakes, rivers, irrigation canals and ponds) and springs in cholera prone communities of Uganda: an analysis of vital physicochemical parameters BMC Public Health volume 20, Article number: 1128.

[13] Shally Sultana Choudhury, Ajay Keot, Hiramoni Das , Mukutamoni Das , Chinmoy Baishy , Aniruddha Sarma and Parag Deka(2016) Preliminary Physicochemical and Microbiological Analysis of Bahini River Water of Guwahati, Assam, India International Journal of Current Microbiology and Applied Sciences ISSN: 2319-7706 Volume 5 Number 2pp. 684-6. 